\title{
ANALISIS KUALITAS KIMIA AIR SUNGAI RIUAPA DAN DAMPAKNYA TERHADAP LINGKUNGAN
}

\author{
THE CHEMICAL QUALITY ANALYSIS OF THE WATERS OF RIUAPA RIVER AND ITS \\ IMPACT ON THE ENVIRONMENT
}

\author{
Elna Soukotta ${ }^{1)}$, Robert Ozsaer ${ }^{2)}$ dan Bokiraya Latuamury ${ }^{3)}$ \\ ${ }^{1)}$ Mahasiswa Program Magister Prodi Manajemen Hutan, Universitas Pattimura \\ ${ }^{2,3)}$ Dosen Program Magister Prodi Manajemen Hutan, Universitas Pattimura \\ Email : soukottaelna12@gmail.com
}

\begin{tabular}{|l|l}
\hline Diterima: 4 Februari 2019 & Disetujui: 20 Maret 2019 \\
\hline
\end{tabular}

\begin{abstract}
Abstrak
Wae Riuapa merupakan sungai utama pada DAS Wae Riuapa yang banyak dimanfaatkan untuk keperluan irigasi pertanian, perikanan tambak serta kebutuhan domestik seperti mandi dan cuci. Sebagai ekosistem perairan terbuka yang mengalir, sungai Riuapa mendapat input dari luar sejak di hulu hingga ke hilir berupa limbah domestik, limbah sisa industri,limbah pertanian dan input dari gangguan bencana alam seperti erosi dan longsor. Studi dilakukan untuk mengidentifikasi kualitas air dengan mengukur tingkat pencemaran air baik di aliran sungai maupun di bantaran sungai khususnya sifat kimia air. Hasil analisis Rancangan Acak Lengkap Faktorial (RALF) model $(3 \times 2 \times 3)$, menunjukkan adanya pengaruh letak stasiun dan musim terhadap kadar variabel BOD, COD, Nitrit dan Chlor pada air sungai maupun air sumur yang melampaui batas ambang baku mutu sehingga berpengaruh terhadap kesehatan lingkungan di sekitarnya. Perubahan tutupan lahan atas DAS Wae Riuapa turut berpengaruh terhadap fluktuasi debit air hujan dan proses pengenceran bahan pencemar sehingga menurunkan kualitas air sungai yang terindikasi pada peningkatan nilai BOD dari $2,9 \mathrm{mg} / \mathrm{l}$ pada musim kemarau menjadi 4,6 mg/l pada musim hujan, COD pada musim kemarau $2,9 \mathrm{mg} / \mathrm{l}$ menjadi $21,3 \mathrm{mg} / \mathrm{l}$ pada musim hujan, Nitrit dari $0,0001 \mathrm{mg} / \mathrm{l}$ pada musim kemarau menjadi $0,0022 \mathrm{mg} / \mathrm{l}$ pada musim hujan.
\end{abstract}

Kata kunci : DAS Waeriuapa, kualitas air, variabel kimia, dampak lingkungan.

\begin{abstract}
Riuapa river is an integrated part of Waeriuapa Watershed that usefull for people around the area as agriculture irrigation, livestock, fresh water fish pond, and other domestic use for people activities. As an open watershed ecosystem, that flow into the sea, the river of Watershed was received various input from outside, either from upland to the estuary. Those input were domestic household waste, farming activities waste, and input from land erosion and land slide. The study was conducted to identify water quality through polutant level measurement, in the river and in the flood plain, especially for Chemical polutant element. Red waste, farming activities waste, and input from land erosion and land slide. The study was conducted to identify water quality through polutant level measurement, in the river and in the flood plain, especially for Chemical polutant element. Result of analisys using Statistical Analisys, namely, Factorial Design in Randomized Completly Design $(3 \times 2 \times 3)$, as follows: Location of station in the river and Season factor was significant influence the chemical variable of BOD, COD, Nitrite, and Chlor in the river, and shallow well as well, at the level of beyond National Water Quality Standard, and affected environmental around the area. Changging of upper land cover of Waeriuapa Watershed was significant effected to water debit, fluctuation of rainfall and effected to liquidity process of water quality, that increase of BOD from $2.9 \mathrm{mg} / \mathrm{l}$ in dry season to $4.6 \mathrm{mg} / \mathrm{l}$ in rainy season; COD from 2.9 in dry season to 21.3 $\mathrm{mg} / \mathrm{l}$ in rainy season; Nitrite content of $0.0001 \mathrm{mg} / \mathrm{l}$ in dry season to $0.0022 \mathrm{mg} / \mathrm{l}$ in rainy season.
\end{abstract}

Keywords: Waeriuapa watershed; Water quality; Chemical Variable; Environmental Impact. 


\section{PENDAHULUAN}

Air merupakan kebutuhan pokok yang tidak bisa terlepas dari kebutuhan manusia. Peningkatan jumlah penduduk dengan berbagai aktivitas yang dilakukan oleh masyarakat juga mempengaruhi jumlah dan kualitas air bersih. Persoalan yang muncul adalah proses penggunaan dan pembuangan air dari aktivitas keseharian masyarakat, kemudian menjadi air limbah dan langsung dibuang ke lingkungan sungai tanpa dilakukan pengolahan terlebih dahulu.

DAS Wae Riuapa merupakan salah satu DAS di wilayah kabupaten Seram Bagian Barat (SBB) yang berperan penting dalam memenuhi kebutuhan masyarakat di berbagai sektor, dari kebutuhan air untuk minum sampai air irigasi. Namun sebagai ekosistem perairan terbuka yang mengalir, sungai Riuapa mendapat input dari luar sejak di hulu hingga ke hilir berupa limbah domestik, limbah sisa industri, limbah pertanian, peternakan dan input dari gangguan bencana alam seperti erosi dan longsor. Hal ini dapat menurunkan kualitas air sungai, mempengaruhi biota perairan, dan secara luas merugikan kehidupan manusia.

Kualitas air sungai merupakan kondisi kualitatif yang diukur berdasarkan parameter tertentu dan dengan metode tertentu sesuai peraturan perundangan yang berlaku. Kualitas air sungai dapat dinyatakan dengan parameter fisika, kimia dan biologi yang menggambarkan kualitas air tersebut (Asdak, 2010). Indikator yang dipakai untuk mengukur kualitas kimia air yaitu berupa $\mathrm{pH}, \mathrm{BOD}, \mathrm{COD}, \mathrm{DO}$, total fosfat, Nitrat, nitrit, logam-logam seperti cadmium, tembaga, seng, besi, mangan, amoniak, dan khlorida.Analisis kualitas air dengan mengukur parameter kimia air sungai Riuapa dan dampaknya terhadap lingkungan dengan melihat perubahan tutupan lahan atas DAS Wae Riuapa merupakan tujuan utama dari penelitian ini. Diharapkan hasil penelitian ini dapat menjadi bahan pertimbangan dan masukan bagi pengelolaan DAS Wae Riuapa dalam upaya pembangunan yang berwawasan lingkungan danmemformulasi kebijakan dalam pengendalian pencemaran dan upaya pemeliharaan kualitas air DAS Wae Riuapa.

\section{METODE PENELITIAN}

Penelitian dilakukan di sungai Riuapa kabupaten Seram Bagian Baratyang merupakan sungai utama di DAS Wae Riuapa.Penelitian ini menggunakan metode survei, analisis laboratorium, dan wawancara responden.Penelitian dilakukan dengan membagi sungai Riuapa menjadi 3 segmen yaitubagian hulu ,tengah dan hilir dimulai dari desa Rambatu, Kecamatan Inamosol sampai desa Waimital dan Kairatu kecamatan Kairatu dengan 15 titik lokasi pengambilan sampel air yaitu satu titik di sungai dan 2 titik pada bantaran kiri dan kanan sungai serta 2 titik pada sumur gali yang ada di bantaran sungai dengan radius < $200 \mathrm{~m}$ (Gambar 1). Penentuan 
stasiun (segmen) pengambilan sampel dilakukan dengan metoda Purposive sampling dengan $2 \mathrm{x}$ ulangan yaitu pada musim penghujan dan musim kemaraudan didasarkan pada pola penggunaan lahan, intensitas aktivitas masyarakat dan jarak dari sungai dengan tetap memperhatikan kemudahan akses, biaya dan waktu (Tabel 3). Analisis sampel air dilakukan di Laboratorium Balai Teknik Kesehatan Lingkungan Provinsi Maluku. Evaluasi kualitas air mengacu pada PP No. 82 Tahun 2001 tentang baku mutu air golongan II dan Permenkes No. 32 Tahun 2017 tentang baku mutu air untuk sanitasi. Hasil evaluasi kualitas air dikaitkan dengan tata guna lahan di kawasan DAS Wae Riuapa dan aktivitas masyarakat yang berada di sekitarnya melalui overlay peta lokasi penelitian dengan Peta Tata Guna Lahan DAS Wae Riuapa dan pengamatan langsung di lapangan. Analisis statistik untuk mengidentifikasi dampak kualitas air sungai terhadap faktor lingkungan menggunakan Rancangan Faktorial dalam Acak Lengkap (RALF) dengan Formula sebagai berikut :

Yijkl $=\mu+\mathrm{Si}+\mathrm{Bj}+\mathrm{Mk}+\mathrm{SiBj}+$ SiMk+BjMk+ SiBjMk $+\sum i j k$

Dimana Yijkl = hasil akibat perlakuan ke $-\mathrm{j}$, perlakuan ke-k dan perlakuan ke-l pada kelompok ke-i, $\mu=$ nilai tengah umum, $\mathrm{Si}=$ pengaruh stasiun $\mathrm{ke}-\mathrm{i}, \mathrm{Bj}=$ pengaruh jarak bantaran ke-j, Mk= pengaruh musim ke-k, $\sum \mathrm{ijk}=$ galat akibat perlakuan ke-j dan perlakuan ke-k pada kelompak ke-i, I = 1,2,..., s ( $\mathrm{s}=$ stasiun $). \mathrm{J}$ $=1,2, \ldots, \mathrm{b} \quad(\mathrm{b}=$ jarak bantaran $)$, $\mathrm{K}=1,2, \ldots, \mathrm{m} \quad(\mathrm{m}=$ musim $)$, Dengan : Faktor $\mathrm{s}=$ stasiun pengukuran (15 stasiun), Faktor $\mathrm{m}=$ musim (musim hujan dan kemarau), Faktor $b=$ jarak bantaran $(50 \mathrm{~m}$, $100 \mathrm{~m}, 150 \mathrm{~m})$.

Selain itu, data sekunder berupa data iklim DAS Wae Riuapa diperoleh dari BMKG Staklim Kairatu dan data hidrologi DAS Wae Riuapa dari Balai Sungai Provinsi Maluku.

\section{HASIL DAN PEMBAHASAN}

Hasil pengukuran kualitas kimia air sungai Riuapa disajikan pada tabel.1

\section{Biochemical Oxygen Demand (BOD)}

\section{Biochemical Oxygen Demand} $(B O D)$ adalah jumlah oksigen terlarut dalam air yang digunakan bakteri untuk proses oksidasi bahan organik seperti karbohidrat, protein, bahan organik dari sumber alami dan polusi dan dinyatakan dalam mg/L atau (ppm) (Hacth et al., 1997, dalam Desmawati, 2014). 


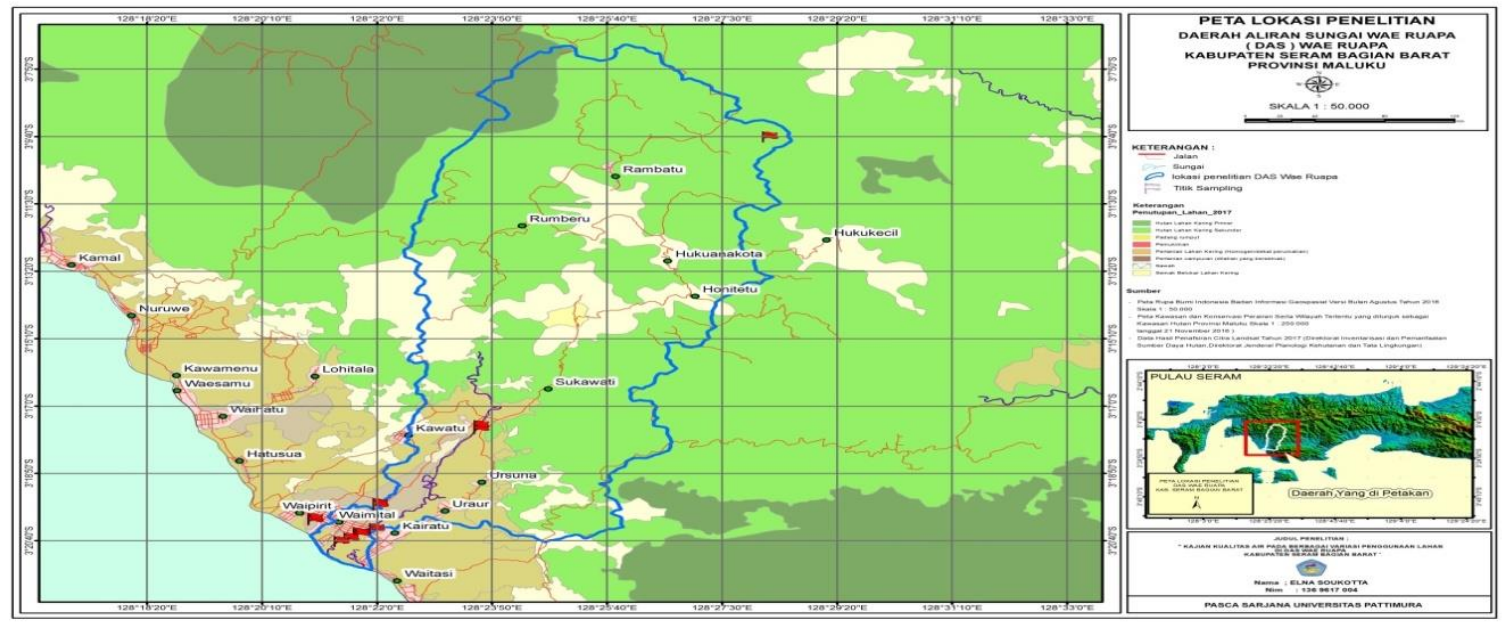

Gambar 1. Lokasi penelitian

Tabel 1. Hasil Pengukuran Kualitas kimia Air Sungai Riuapa Kabupaten Seram Bagian Barat

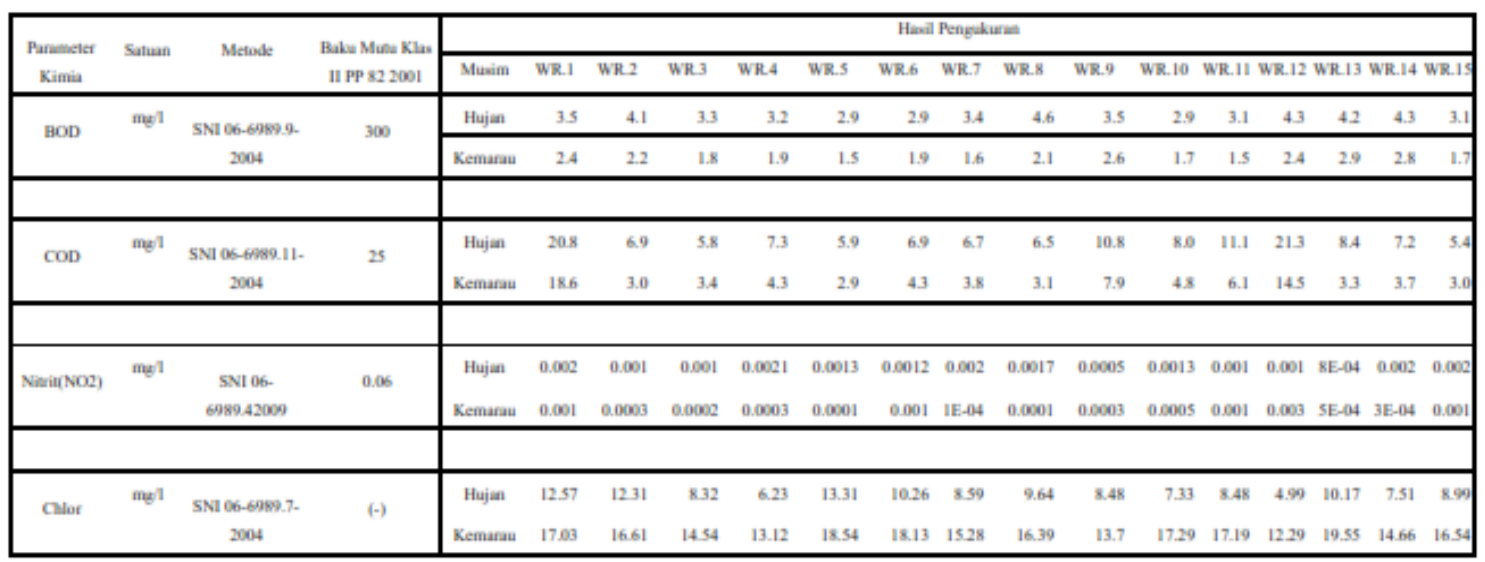


Hasil analisis BOD antara musim hujan dan musim kemarau relatif bervariasi untuk semua titik sampling. Analisis BOD pada musim hujan berkisar antara $2,9 \mathrm{mg} / \mathrm{l}$ 4,6 mg/l dan rata-rata BOD musim hujan 3,5 $\mathrm{mg} / \mathrm{l}$. Kadar BOD tertinggi $(4,6 \mathrm{mg} / \mathrm{l})$ pada musim hujan terdapat di lokasi sampling WR.8(Saluran Irigasi tengah 1), dan kadar BOD terendah $(2,9 \mathrm{mg} / \mathrm{l})$ terdapat di titik sampling WR.5(Daerah Tambak Ikan), WR.6 (Gedung Putih Irigasi II), dan WR.10 (Saluran Irigasi tengah 2). Sementara analisis BOD pada musim kemarau berkisar antara 1,5 mg/l - 2,9 mg/l dengan kadar BOD ratarata $2,1 \mathrm{mg} / \mathrm{l}$. Kadar BOD tertinggi musim kemarau $(2,9 \mathrm{mg} / \mathrm{l})$ terdapat pada lokasi sampling WR.13(Wae Riuapa Hilir 3), dan kadar BOD terendah pada musim kemarau $(1,5 \mathrm{mg} / \mathrm{l})$ terdapat pada lokasi sampling WR.5 (Daerah tambak Ikan) dan WR. 11 (Wae Riuapa Hilir 3).

Berdasarkan baku mutu kelas II PP No. 82 Tahun 2001, BOD yang dipersyaratkan adalah $\pm 3 \mathrm{mg} / \mathrm{l}$. BOD musim hujan rata-rata melebihi ambang baku mutu sementara BOD untuk musim kemarau relatif dibaambang baku mutu. Kenaikan kadar BODtinja hewan dalam air sungai Riuapa maupun dalam saluran irigasi petani serta juga terkontaminasi ke sumur warga. Hal ini senada dengan terjadi pengenceran zat-zat pencemar yang berupa limbah domestik dan pada musim hujan mengindikasikan bahwa terjadi pengenceran zat-zat pencemar yang berupa limbah domestik dan tinja hewan dalam air sungai Riuapa maupun dalam saluran irigasi petani serta juga terkontaminasi ke sumur warga.Hal ini senada dengan pendapat Hacth et al., 1997, dalam Desmawati, (2014) yakni bahwa tingginya kadar BOD dalam air sungai mengindikasikan banyaknya bakteri yang terdapat di air. Interaksi musim hujan dan musim kemarau terhadap kadar BOD menunjukkan pada musim hujan di semua stasiun pengamatan kadar BOD meningkat dan pada musim kemarau kadar BOD menurun secara signifikan. Variasi kandungan BOD pada musim hujan dan kemarau disajikan pada Gambar 2.

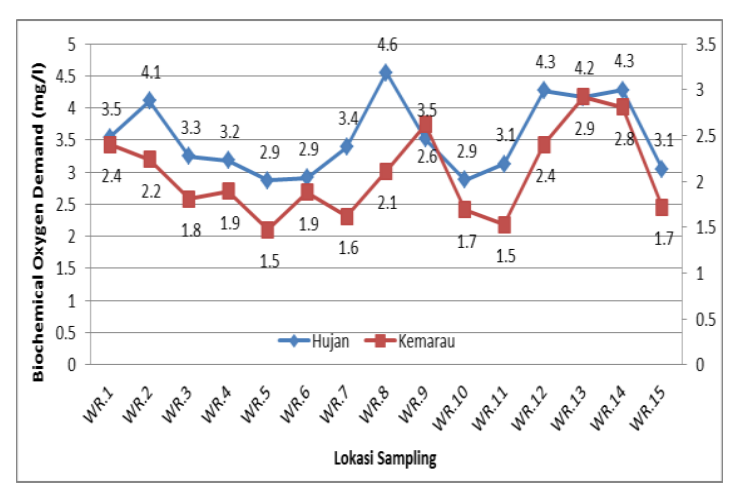

Gambar 2.Grafik Kadar BOD kualitas kimia air di DAS Wae Riuapa Kab. SBB

Nilai BOD digunakan untuk menentukan tingkat pencemaran di suatu perairan hal ini sebagai indikasi bahwa terjadi proses oksidasi oleh bakteri. Air yang bersih dan dapat digunakan adalah memiliki kadar 
oksigen yang cukup dan tidak mengandung banyak bakteri yang dapat membahayakan jika dikonsumsi.

\section{Chemical Oxygen Demand (COD)}

COD menggambarkan jumlah total oksigen yang dibutuhkan untuk mengoksidasi bahan organik secara kimiawi, baik yang dapat didegradasi secara biologis maupun yang sukar didegradasi secara biologis menjadi $\mathrm{CO}_{2}$ dan $\mathrm{H}_{2} \mathrm{O}$.

Hasil analisis COD antara musim hujan dan musim kemarau relatif bervariasi untuk semua titik sampling. Kadar COD pada musim hujan berkisar antara $5,4 \mathrm{mg} / \mathrm{l}$ $21,3 \mathrm{mg} / \mathrm{l}$ dan rata-rata COD musim hujan 9,3 mg/l. Kadar COD tertinggi $(21,3 \mathrm{mg} / \mathrm{l})$ pada musim hujan terdapat pada lokasi titik sampling WR.12(Wae Riuapa Hilir 2), dan kadar COD terendah $(5,4 \mathrm{mg} / \mathrm{l})$ terdapat pada titik sampling WR.15(Saluran Irigasi Hilir). Sementara analisis COD pada musim kemarau berkisar antara 2,9 mg/l - 18,6 mg/l dengan kadar COD rata-rata 5,8 mg/l. Kadar COD tertinggi musim kemarau $(18,6 \mathrm{mg} / \mathrm{l})$ terdapat pada lokasi titik sampling WR.1(Hulu Wai Riuapa 1), dan kadar COD terendah pada musim kemarau $(2,9 \mathrm{mg} / \mathrm{l})$ terdapat pada lokasi titik sampling WR.5(Daerah Tambak Ikan) .Tingginya kadar COD pada lokasi Hulu dan hilir Wae Riuapa disebabkan karena banyak serasah daun dan ranting (sampah organik) yang jatuh dan limbah domestik dalam air sehingga membuat konsentrasi COD meningkat. Hal ini didukung oleh pendapat Efendi, (2003), yang mengatakan bahwa kadar COD menggambarkan jumlah total oksigen yang dibutuhkan untuk mengoksidasi bahan organik secara kimiawi, baik yang dapat didegradasi secara biologis maupun yang sukar didegradasi secara biologis menjadi $\mathrm{CO}_{2}$ dan $\mathrm{H}_{2} \mathrm{O}$. Tingginya kadar $\mathrm{COD}$ ini mengindikasikan tingginya kadar bahan pencemar yang terdapat dalam air sungai.

Berdasarkan baku mutu kelas II PP No. 82 Tahun 2001 COD yang dipersyaratkan adalah $\pm 25 \mathrm{mg} / \mathrm{l}$. Hasil analisis COD untuk musim hujan dan musim kemarau pada semua lokasi sampling berada dibawah ambang baku mutu. interaksi musim hujan terhadap kadar COD cukup tinggi sedangkan musim kemarau kadar COD menurun untuk semua titik sampel seperti disajikan pada Gambar.3.

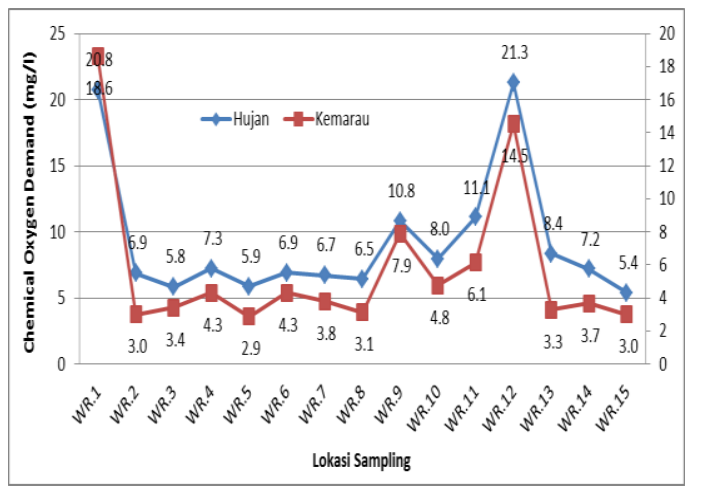

Gambar 3. Kadar COD kualitas kimia air di DAS Wae Riuapa Kab. SBB 
Nilai parameter COD lebih besar dari nilai BOD, karena COD menghitung semua kebutuhan oksigen untuk proses oksidasi, sedangkan BOD hanya memperhitungkan oksigen yang dibutuhkan oleh bakteri saja (Effendi, 2003).

\section{Nitrit $\left(\mathrm{NO}_{2}\right)$}

Hasil analisis Nitrit $\left(\mathrm{NO}_{2}\right)$ antara musim hujan dan musim kemarau relatif bervariasi untuk semua titik sampling. Analisis nitrit pada musim hujan berkisar antara $0,0005 \mathrm{mg} / \mathrm{l}-0,0022 \mathrm{mg} / \mathrm{l}$ dan ratarata nitrit musim hujan $0,0014 \mathrm{mg} / \mathrm{l}$. Kadar nitrit tertinggi pada musim hujan $(0,0022$ $\mathrm{mg} / \mathrm{l})$ terdapat pada lokasi titik sampling WR.1(Hulu Wai Riuapa 1), dan kadar nitrit terendah $(0,0005 \mathrm{mg} / \mathrm{l})$ terdapat pada titik sampling WR.5(Daerah Tambak Ikan). Sementara analisis nitrit pada musim kemarau berkisar antara 0,0001 mg/l - 0,0030 mg/l dengan kadar nitrit rata-rata $0,0007 \mathrm{mg} / \mathrm{l}$. Kadar nitrit tertinggi musim kemarau (0,0030 $\mathrm{mg} / \mathrm{l})$ terdapat pada lokasi titik sampling WR.12(Wae Riuapa Hilir 2), dan kadar nitrit terendah pada musim kemarau $(0,0001 \mathrm{mg} / \mathrm{l})$ terdapat pada lokasi titik sampling WR.5(Daerah Tambak Ikan), WR.7 (Gedung Putih Irigasi 1), dan WR.8 (Saluran Irigasi Tengah 1).

Berdasarkan baku mutu kelas II PP No. 82 Tahun 2001 nitrit yang dipersyaratkan adalah $1 \mathrm{mg} / \mathrm{l}$. Hasil analisis nitrit untuk semua lokasi sampling berada dibawah ambang baku mutu. interaksi musim hujan terhadap kadar nitrit lebih tinggi daripada interaksi musim kemarau, kecuali stasiun WR.12 kadar nitritnya berlawanan dimana pada musim hujan rendah dan meningkat secara signifikan pada musim kemarau. seperti disajikan pada Gambar 4.

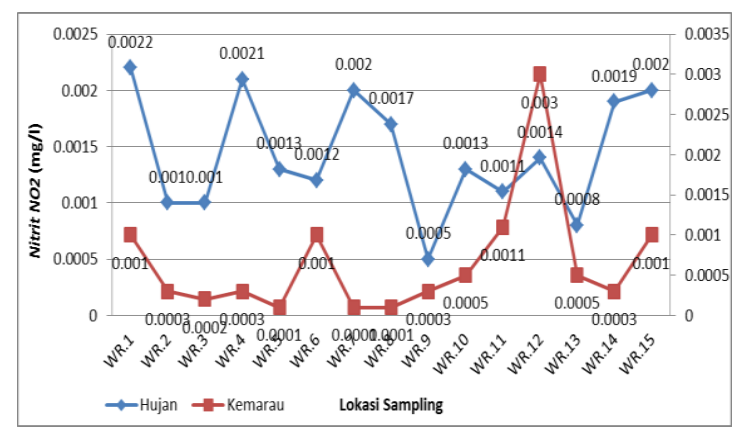

Gambar 4.Grafik Kadar Nitrit $\left(\mathrm{NO}_{2}\right)$ kualitas kimia air di DAS Wae Riuapa

\section{Khlor}

Hasil analisis khlor (Cl) antara musim hujan dan musim kemarau relatif bervariasi untuk semua titik sampling. Analisis khlor pada musim hujan berkisar antara 4,989 mg/l -13,312 mg/l dan rata-rata khlor musim hujan 9,145 mg/l. Kadar khlor tertinggi pada musim hujan $(13,312 \mathrm{mg} / \mathrm{l})$ terdapat di lokasi titik sampling WR.5(Daerah Tambak Ikan), dan kadar khlor terendah $(4,989 \mathrm{mg} / \mathrm{l})$ terdapat pada titik sampling WR.12(Wae Riuapa Hilir 2). Sementara analisis khlor pada musim kemarau berkisar antara 12,290 mg/l $19,549 \mathrm{mg} / \mathrm{l}$ dengan kadar khlor rata-rata $16,057 \mathrm{mg} / \mathrm{l}$. Kadar khlor tertinggi musim 
kemarau $(19,549 \mathrm{mg} / \mathrm{l})$ terdapat pada lokasi titik sampling WR.13(Wae Riuapa Hilir 3), dan kadar khlor terendah pada musim kemarau $(12,290 \mathrm{mg} / \mathrm{l})$ terdapat pada lokasi sampling WR.12(Wae Riuapa Hilir 2).

Berdasarkan baku mutu kelas II PP No. 82 Tahun 2001 khlor yang dipersyaratkan adalah (-). Hasil analisis khlor untuk musim hujan dan musim kemarau pada semua lokasi sampling berada dibawah ambang baku mutu. interaksi musim terhadap kadar khlor pada musim hujan rendah dan pada musim kemarau meningkat secara signifikan terutama di titik sampling WR.13(Wae Riuapa Hilir 3), seperti disajikan pada Gambar 5.

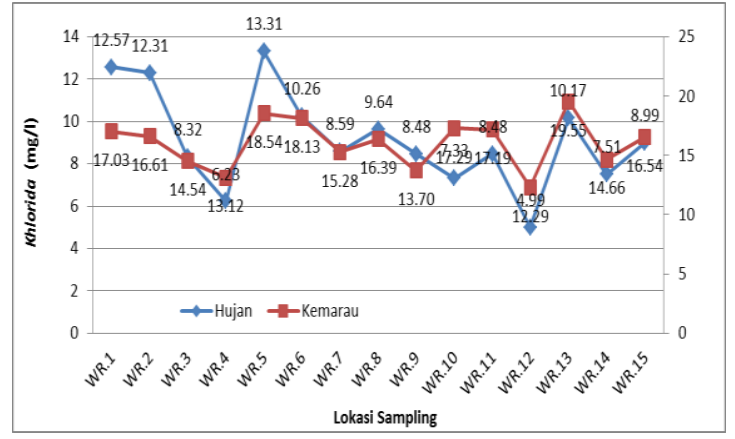

Gambar 5. Kadar Khlor kualitas kimia air di DAS Wae Riupa Kab. SBB.

Khlorida adalah senyawa halogen khlor $(\mathrm{Cl})$. Toksisitasnya tergantung pada gugus senyawanya, misalnya $\mathrm{NaCl}$ sangat tidak beracun tapi karbonil khlorida sangat beracun. Di Indonesia khlor digunakan sebagai desifektan pada penyediaan air minum. Dalam jumlah banyak khlor akan menimbulkan rasa asin, korosi pada pipa sistem penyedia air panas.

Analisis uji beda nyata kualitas kimia air untuk variabel BOD, COD, Nitrit, dan Chlor menunjukkan bahwa secara keseluruhan terdapat perbedaan yang signifikan antara musim hujan dan musim kemarau pada semua titik sampling dengan nilai yang bervariasi. Hasil perbandingan dengan nilai standar baku mutu Air kelas II menunjukkan bahwa terdapat parameter kimia yang melebihi standar baku mutu yaitu variabel BOD. Hal ini mengindikasikan bahwa secara keseluruhan kualitas air sungai Riuapa tidak memenuhi syarat dapat mempengaruhi kesehatan masyarakat yang mengkonsumsinya.

Variabel BOD dan COD menjadi indikator banyaknya sampah organik yang mencemari air sungai di kawasan DAS Wae Riuapa.Banyaknya senyawa organik ini dapat dikaitkan dengan aktivitas masyarakat yang berlangsung di sepanjang DAS Berdasarkanpengamatan, pada stasiun-stasiun yang memiliki kadar BOD dan COD tinggi memang terlihat adanya sampah organik maupun anorganikyang berasal dari limbah rumah tangga. Hal ini senada dengan hasil penelitian Yetty dkk, (2011) yang mengatakan bahwa karena banyaknya kandungan sampah organik dan anorganik menyebabkan sungai yang berwarna keruh. 
Air yang dibutuhkan oleh tubuh manusia harus bersih, baik dari sumbernya maupun dari air itu sendiri. Air yang tidak bersih akan menyebabkan penurunan kualitas hidup organisme yang mengkonsumsinya karena di dalam air yang kurang bersih banyak mikroba ataupun zat-zat kimia terlarut yang membahayakan tubuh. Sumber air untuk keperluan hidup organisme pada umumnya berasal dari air sungai karena tingkat salintasnya yang rendah sehinggga dapat dimanfaatkan sebagai sumber air minum ( Rijal, 2013).

Secara signifikan kadar bahan pencemar yang terkandung dalam air dipengaruhi oleh musim dan letak stasiun. Dari hulu ke hilir terdapat perubahan yang signifikan. Pada musim hujan, kadar beberapa bahan pencemar meningkat di stasiun yang berada pada segmen tengah dan hilir sungai Riuapa. Karena pada segmen ini terdapat aktifitas manusia dan merupakan daerah pertanian (persawahan), peternakan tanpa kandang dan permukiman yang dominan sehingga banyak menyumbang limbah ke alam.

Perubahan penutupan lahan atas DAS Wae Riuapa berpengaruh pada jumlah dan debit air sungai Riuapa. Hasil penelitian menunjukkan bahwa debit air dan ketinggian air sungai Riuapa turut terpengaruh oleh perubahan penutupan lahan dan musim dimana untuk tahun 2018 pada bulan Agustus ketinggian air sungai Riuapa sangat tinggi dengan debit air mencapai $0,1.06 .13 \mathrm{~m} /$ detik kemudian berangsur-angsur menurun hingga bulan Desember dimana debit air sungai Riuapa sebesar $03.01 .48 \mathrm{~m} /$ detik dengan ketinggian air hanya mencapai kisaran antara $25 \mathrm{~cm}$ (pada daerah hulu) dan debit air 01.39.06 m/detik dengan ketinggian air mencapai $35 \mathrm{~cm}$ pada bagian hilir. Hal ini mengindikasikan bahwa peningkatan debit air sungai berpengaruh dalam proses pengenceran dan pelarutan ion-ion yang terkandung dalam tanah, yang terlihat pada nilai parameter uji dimana pada musim hujan, kandungan BOD, COD, Nitrit dan Chlor meningkat pada beberapa titik yaitu WR.1(Nitrit 0,0022mg/l; COD 20,1mg/l), WR.8 (BOD 4,6 mg/l), WR.12 (COD 21,3mg/l; Nitrit 0,003 mg/l), WR.13 (BOD 4,2mg/l; Chlor 19,549mg/l), yang mewakili segmen hulu (WR.1), segmen Tengah (WR.8) dan segmen hilir sungai Riuapa (WR.12, WR.13). Hal ini senada dengan hasil penelitian Suryo dkk (2014), bahwa Faktor yang berpengaruh terhadap mutu air adalah aktifitas manusia dan proses alam karena dari segmen hulu hingga hilir terdapat perubahan penggunaan lahan dominan, sehingga tingkat pencemaran dan kandungan bahan pencemar bervariasi sesuai dengan jenis tata guna lahan. Supingat (2008) dalam Agustiningsih (2012), juga mengatakan bahwa daerah hulu dengan pola pemanfaatan lahan yang relatif seragam, 
mempunyai kualitas air yang lebih baik dari daerah hilir dengan pola penggunaan lahan yang beragam. Semakin kecil tutupan hutan dalam sub DAS serta semakin beragamnya jenis penggunaan lahan dalam sub DAS menyebabkan kondisi kualitas air sungai yang semakin buruk, terutama akibat adanya aktivitas pertanian dan pemukiman.

\section{KESIMPULAN DAN SARAN}

\section{Kesimpulan}

Hasil analisis variabel COD, Nitrit dan Chlorberada di bawah ambang baku mutu berdasarkan baku mutu air kelas II PP No. 82 tahun 2001 yang menunjukkan kadar parameter pencemar dalam air sungai dan air sumur masih cukup rendah kecuali variabel BODberada di atas ambang baku mutu dengan nilai rata-rata hujan $3,5 \mathrm{mg} / \mathrm{l}$ (bm $\mathrm{BOD}=3 \mathrm{mg} / \mathrm{l}$ ), sehingga dapat mempengaruhi kesehatan masyarakat yang mengkonsumsinya.

Perubahan tutupan lahan DAS Wae Riuapa mengakibatkan perubahan debit air sungai yang berpengaruh dalam proses pengenceran dan pelarutan bahan pencemar, yang terindikasi pada peningkatan nilai BOD dari 2,9 mg/l pada musim kemarau menjadi 4,6 mg/l pada musim hujan, COD pada musim kemarau 2,9 mg/l menjadi $21,3 \mathrm{mg} / \mathrm{l}$ di musim hujan, nitrit dari $0,0001 \mathrm{mg} / \mathrm{l}$ pada musim kemarau menjadi $0,0022 \mathrm{mg} / \mathrm{l}$ pada musim hujan.

\section{DAFTAR PUSTAKA}

Agustiningsih, D. 2012. Kajian Kualitas Air Sungai Blukar Kabupaten Kendal Dalam Upaya Pengendalian Pencemaran Air Sungai. Tesis Magister Ilmu Lingkungan. Universitas Diponegoro. Semarang.

Asdak, C. 2010. Hidrologi dan Pengelolaan Daerah Aliran Sungai. Gajahmada University Press. Yogyakarta.

Desmawati, E.2014. Sistem Informasi Kualitas Air Sungai di Wilayah Sungai Seputih Sekampung. Tesis Magister Teknik Universitas Lampung. Bandar Lampung.

Effendy, H. 2003. Telaah Kualitas Air bagi Pengelolaan Sumber Daya dan Lingkungan Perairan. Penerbit kanasius. Yogyakarta.

Rijal, M. 2013. Kualitas Air Sungai Arbes Ambon Berdasarkan Nilai Koliform Fecal. Program Studi Pendidikan Biologi. IAIN AMBON.

Republik Indonesia. 2001. Peraturan Pemerintah Nomor 82 Tahun 2001 tentang Pengelolaan Kualitas Air dan Pengendalian Pencemaran Air. Jakarta: Sekretariat Negara.

Republik Indonesia. 2017. Peraturan Menteri Kesehatan Nomor 32 Tahun 2017 tentang Standar Baku Mutu Lingkungan dan Persyaratan Kesehatan Air Keperluan Sanitasi, Kolam Renang, Solus per Aqua.

Suryo, A.W., Winardi, D. N., Endro, S. 2014.Analisis Kualitas Air Sungai Bringin Kota Semarang Dengan Metode Nsf - Ika 
Yetti, E., Soedharma, D., Sigid, D.,Haryadi,S., 2011. Evaluasi Kualitas Air Sungai-Sungai Di Kawasan Das Brantas Hulu Malang. Tesis. IPB Bogor. 